\title{
Nilai Ekonomi Substitusi Jagung Lokal dalam Ransum Komersial pada Ayam F1 Hasil Persilangan Berbeda Strain
}

\section{Economic Value of Local Corn Substitution in Commercial Rations on F1 Chicks Results of Different Crosses Strains}

\author{
F. Lopi*, R. L. Ulrikus dan F. M. S. Telupere \\ Program Pascasarjana, Prodi Ilmu Peternakan, Universitas Nusa Cendana \\ Jln Adisucipto Penfui, Kupang, NTT \\ *Corresponding email: lopifabianus@gmail.com
}

\begin{abstract}
A research has been carried out to determine the economic value of local corn substitution in commercial F1 rations resulting from crossing of local males with different strains from the Isa Brown laying race. This cross produced 72 chickens which were used as research material. The method used was an experimental method with a design using factorial completely randomized design (RCD) consisting of $23 \times 2$ pattern factors namely: 3 male strain factors (Sabu male $>\langle$ Isa Brown $=$ Saras, Bangkok $\rangle\langle$ Isa Brown $=$ Bakoras and Legund $\rangle\langle$ Isa Brown $=$ Leguras) and 2 feed factors $(100 \%$ commercial feed $=\mathrm{P} 1$ and $70 \%$ commercial feed $+30 \%$ local corn $=\mathrm{P} 2)$. The combination of these two factors resulted in 6 treatment combinations namely: Saras chicken were fed P1 (SP1), Saras chicken were fed P2 (SP2), Bakoras chicken were fed P1 (BP1), Bakoras chicken were fed P2 (BP2), Leguras chickens were fed P1 (LP1) and Leguras chickens were given P2 feed (LP2). Economic value variables in this study were performance index (IP) and income over feed and chick cost (IOFCC). The data obtained were analyzed for variance, if it had a significant effect $(\mathrm{P}<0.05)$ followed by the Least Significant Difference test (LSD) to determine the difference between the treatment combination with the Microsoft Excel application and SPSS 21. The results of this study indicated that the interaction between strain factor and feed factor significantly affected $(\mathrm{P}<0.01)$ on IP and IOFCC values per Saras, Bakoras and Leguras chickens. The best treatment combination in this study was obtained at BP1 treatment with an IP value of 82.94 and IOFCC of Rp. 93,955.15/head.
\end{abstract}

Key words: crossbreed, commercial feed, local corn, economic value.

\begin{abstract}
ABSTRAK
Penelitiaan ini telah dilakukan untuk mengetahui nilai ekonomi substitusi jagung lokal dalam ransum komersial ayam F1 hasil silangan pejantan lokal yang berbeda strain dengan ras petelur Isa Brown. Silangan ini menghasilkan 72 ekor ayam yang digunakan sebagai materi penelitian. Metode yang digunakan adalah metode eksperimen dengan desain menggunakan Rancangan Acak Lengkap (RAL) faktorial yang terdiri dari 2 faktor pola 3x2 yakni: 3 faktor strain pejantan (pejantan Sabu $><$ Isa Brown $=$ Saras, Bangkok $\rangle\langle$ Isa Brown $=$ Bakoras dan Legund $><$ Isa Brown = Leguras) dan 2 faktor pakan (pakan komersial 100\% $=\mathrm{P}_{1}$ dan pakan komersial $70 \%$ $+30 \%$ jagung lokal $=\mathrm{P}_{2}$ ). Kombinasi kedua faktor ini menghasilkan 6 kombinasi perlakuan yakni: ayam Saras diberi pakan $\mathrm{P}_{1}\left(\mathrm{SP}_{1}\right)$, ayam Saras diberi pakan $\mathrm{P}_{2}\left(\mathrm{SP}_{2}\right)$, ayam Bakoras diberi pakan $\mathrm{P}_{1}\left(\mathrm{BP}_{1}\right)$, ayam Bakoras diberi pakan $\mathrm{P}_{2}\left(\mathrm{BP}_{2}\right)$, ayam Leguras diberi pakan $\mathrm{P}_{1}\left(\mathrm{LP}_{1}\right)$ dan ayam Leguras diberi pakan $\mathrm{P}_{2}\left(\mathrm{LP}_{2}\right)$. Variabel nilai ekonomi dalam penelitian ini adalah indeks performa (IP) dan income over feed and chick cost (IOFCC). Data yang diperoleh dilakukan analisis ragam, apabila berpengaruh nyata $(\mathrm{P}<0,05)$ dilanjutkan uji Beda Nyata Terkecil (BNT) untuk mengetahui perbedaan antara kombinasi perlakuan dengan aplikasi microsoft excel dan SPSS 21. Hasil penelitian ini menunjukkan bahwa interaksi antara faktor strain dan faktor pakan berpengaruh sangat nyata $(\mathrm{P}<0,01)$ terhadap nilai IP dan IOFCC per ekor ayam Saras, Bakoras dan Leguras. Kombinasi perlakuan terbaik dalam penelitian ini diperoleh pada perlakuan $\mathrm{BP}_{1}$ dengan nilai IP 82,94 dan IOFCC sebesar Rp93.955,15/ekor.
\end{abstract}

Kata kunci: persilangan, pakan komersial, jagung lokal, nilai ekonomi.

\section{PENDAHULUAN}

Peternakan merupakan subsektor yang mempunyai peranan penting dalam meningkatkan pendapatan petani di Provinsi Nusa Tenggara Timur (NTT). Peranan tersebut dapat dilihat dari tingkat permintaan produk peternakan yang meningkat seiring dengan pemahaman masyarakat akan pentingnya protein hewani terhadap pertumbuhan dan perkembangan tubuh manusia. Salah satu ternak yang 
menghasilkan produk berupa daging dan telur adalah ayam buras.

Ayam buras memiliki prospek yang cerah, meskipun pemeliharaannya dilakukan secara tradisional oleh sebagian besar masyarakat pedesaan. Daya tarik masyarakat untuk beternak ayam buras adalah selalu mengalami peningkatan dan fluktuasi harganya tetap, sistem penjualan produk ayam tidak berdasarkan satuan berat $(\mathrm{kg})$, tetapi didasarkan pada satuan ekor (untuk daging). Selain itu, ayam buras memiliki daya tahan tubuh yang lebih baik dibandingkan ayam ras dan memiliki daya adaptasi yang baik terhadap lingkungan yang buruk (Suprijatna, 2005).

Prospek usaha ayam buras yang baik di pasaran tidak didukung dengan bibit dan pakan dari sisi kualitas maupun kuantitas. Di samping itu, lemahnya sumberdaya para peternak untuk menyerap teknologi pakan dan perbaikan mutu genetik juga menjadi masalah dalam pengembangan usaha ayam buras di NTT. Produksi telur ayam buras mencapai 30\% (105 butir/ekor/tahun) dengan pemeliharaan secara intensif sedangkan ayam ras mencapai 351 butir/ekor/tahun (Telupere dan Sutedjo, 2016). Masalah ini menyebabkan para peternak mempertahankan usaha ayam buras dalam sistem tradisional dimana hanya sebatas memenuhi kebutuhan rumah tangga dengan pakan dan bibit seadanya.

Usaha untuk meningkatkan kinerja produksi dan produktivitas ayam lokal di NTT dapat ditempuh melalui tiga pendekatan perbaikan, yakni perbaikan breeding (mutu genetik), feeding (pakan) dan manajemen. Salah satu terobosan teknologi budidaya adalah melakukan persilangan ayam kampung jantan dengan ayam ras petelur untuk menghasilkan ayam niaga dengan pertumbuhan cepat dan cita rasa dagingnya sama dengan ayam kampung (Kaleka, 2015). Betina ayam ras petelur Isa Brown sebagai indukan memiliki kemampuan bertelur cukup tinggi sehingga menjamin ketersediaan DOC ayam buras dengan hand day production (HDP) $78,04 \pm 0,48 \%$ dan berat telur 65,36 $\pm 0,29 \mathrm{~g} / \mathrm{butir}$ (Shidiq dan Amarullah, 2016).

Hasil silang ayam kampung jantan dengan ayam petelur yang diberi nama ayam kampung Super atau Jawa Super dapat dipanen dengan bobot badan $0,8-1 \mathrm{~kg}$ setelah dipelihara selama 55-60 hari (Kaleka, 2015). Perbaikan mutu genetik ayam lokal juga telah dilakukan di NTT untuk meningkatkan performa ayam kampung dan mengurangi biaya produksi dengan mendatangkan DOC ayam kampung Super dari daerah lain. Bandu et al (2015) melaporkan bahwa persilangan ayam petelur dengan strain pejantan (Bangkok, Prancis dan kampung) tidak memberikan pengaruh yang negatif dan relatif sama dengan rataan berat telur $61,73 \mathrm{~g} / \mathrm{butir}$, daya tetas $54,36 \%$ dan berat DOC 54,49 g/ekor.

Djegho et al (2019) melaporkan bahwa komposisi genotip hasil silang ras petelur, Kate dan lokal Sabu dari PEKASA (1/2 petelur, 1/4 Kate, 1/4 Sabu) menampilkan sifat bobot badan dan ukuran tubuh yang lebih baik dari KAPESA (1/2 Kate, 1/4 petelur, 1/4 Sabu) pada umur 12 minggu. Selanjutnya Lapihu et al (2019) melaporkan bahwa hasil persilangan antara pejantan lokal yakni ayam Sabu, ayam Bangkok dan ayam Leher Gundul dengan betina ras petelur Isa Brown memberikan pengaruh yang positif dan nyata terhadap peningkatan performa produksi daging dengan menggunakan pakan komersial ayam ras pedaging.

Pakan merupakan komponen terbesar dari seluruh biaya dalam usaha unggas yang bisa mencapai 70\% (Nawawi dan Nurohhmah, 2011). Penggunaan pakan komersial ayam ras pedaging pada ayam buras menyebabkan peningkatan biaya produksi. Hal ini dikarenakan harganya yang relatif tinggi dengan rentang waktu pemeliharaan yang lebih lama dan kebutuhan nutrisi yang kurang tepat.

Ayam kampung memiliki kebutuhan protein yang lebih rendah jika dibandingkan dengan ayam ras pedaging. Ayam ras pedaging fase starter membutuhkan energi metabolisme sebesar $3.080 \mathrm{kkal} / \mathrm{kg}$ dan protein antara 2324\%, pada fase finisher memerlukan energi $3.080-3.190 \mathrm{kkal} / \mathrm{kg}$ dan protein $19-21 \%$ (Wahyu, 1992). Selanjutnya ayam kampung fase starter membutuhkan protein 19-20\% dan energi metabolisme $2.850 \mathrm{kkal} / \mathrm{kg}$, fase grower I protein 18-19\% dan energi metabolis $2.900 \mathrm{kkal} / \mathrm{kg}$, fase gower II membutuhkan protein 16-18\% dan energi metabolis sebesar $3.000 \mathrm{kkal} / \mathrm{kg}$ (Nawawi dan Nurohhmah, 2011).

Berdasarkan kebutuhan nutrisi ayam tersebut, maka untuk menunjang produktivitas daging ayam lokal unggul di NTT yang bersifat komersial dapat dilakukan melalui optimalisasi penggunaan pakan lokal untuk menekan biaya produksi. Salah satu strategi yang mudah untuk menekan biaya pakan adalah dengan mensubstitusi jagung lokal dalam pakan komersial ayam ras pedaging dengan komposisi yang tidak mengganggu kebutuhan nutrisi ayam kampung. 
Substitusi jagung dalam ransum komersial perlu mempertimbangkan kualitas dan kuantitas jagung tingkat nasional maupun di tingkat daerah. Jagung lokal NTT (tunu'ana) memiliki kandungan protein sebesar $11,78 \%$ dan energi metabolis sebesar 3.801,9 kkal/kg (Bora et $a l, 2019)$. Beramang (2012) menyatakan bahwa kandungan protein jagung lokal kuning di Kabupaten Flores Timur adalah $10,82 \%$. Di samping itu, produksi jagung nasional tahun 2014-2017 mengalami peningkatan sebesar $34,3 \%$ dari 19,01 juta ton menjadi 28,92 juta ton. Selanjutnya diproyeksi akan meningkat sebesar 3,63\% pada tahun 2018 (BPS, 2018 diolah).

Produksi jagung di NTT pada tahun 2014-2017 juga mengalami peningkatan sebesar $20,1 \%$ dari 647.108 ton menjadi 809.830 ton (BPS, 2018 diolah). Ketersediaan jagung di NTT didukung program Tanam Jagung Panen Sapi (TJPS) pemerintah melalui Dinas Pertanian Provinsi NTT pada tahun 2018 dengan sasaran 7 kabupaten berbasis lahan kering seluas 2.400 ha dengan proyeksi produksi 4-5 ton/ha dengan HPP jagung Rp3.200/kg pipilan kering (Dinas Pertanian Provinsi NTT, 2018).

Berdasarkan produksi jagung secara nasional maupun di NTT khususnya yang mendukung secara kuantitas, kualitas dan ekonomis sebagai pakan ternak, maka perlu adanya upaya manipulasi pakan dengan substitusi jagung lokal dalam ransum komersial ayam ras pedaging sebanyak 30\%. Kandungan nutrisi penambahan jagung lokal sebanyak 30\% dalam ransum komersial menghasilkan protein kasar $17 \%$ dan energi metabolis sebesar 3.240,57$3.380,57 \mathrm{kkal} / \mathrm{kg}$. Oleh karena itu, telah dilakukan penelitian dengan judul Analisis Ekonomi Substitusi Jagung dalam Ransum Komersial pada Ayam F1 Hasil Persilangan berbeda Strain.

\section{MATERI DAN METODE}

Penelitian ini telah dilaksanakan di Kelurahan Naikoten 1, Kecamatan Kota Raja selama 3 bulan yang terdiri dari 1 minggu pengumpulan telur, 3 minggu penetasan dan 8 minggu perlakuan pakan terhadap DOC hasil persilangan pada tahun 2018. Ternak yang digunakan dalam penelitian ini adalah 72 ekor DOC F1 hasil silangan unsexed antara pejantan lokal berbeda strain dan ras petelur Isa Brown dengan jumlah masing-masing kelompok silangan adalah 24 ekor. Kandang yang digunakan dalam penelitian ini adalah kandang sistem baterai berukuran $1 \mathrm{~m}^{2}$ sebanyak 18 kotak. Pakan yang digunakan adalah pakan komersial $\mathrm{BR}_{1}$ untuk fase starter (1-4 minggu) sedangkan pada fase grower (5-8 minggu) diberi substitusi jagung giling lokal sebanyak $30 \%+70 \%$ pakan komersial BR2 $\left(\mathrm{P}_{1}\right)$ dan pakan komersial BR2 $100 \%\left(\mathrm{P}_{2}\right)$.

Tabel 1. Kandungan nutrisi pakan komersial dan jagung lokal

\begin{tabular}{llll}
\hline \multirow{2}{*}{ Komposisi } & \multicolumn{3}{c}{ Pakan } \\
\cline { 2 - 4 } & \multicolumn{1}{c}{ BR1* } & \multicolumn{1}{c}{ BR2* } & Jagung giling** \\
\hline Protein kasar (\%) & $20-22$ & $19-21$ & 11,78 \\
Lemak kasar (\%) & Min 5,0 & Min 5 & 5,59 \\
Serat kasar (\%) & Max 5,0 & Max 5 & 6,84 \\
Kalsisum (\%) & Min 0,9 & Min 0,7 & 0,12 \\
Pospor (\%) & Min 0,6 & Min 0,6 & 4,5 \\
Energi metabolis (kkal/kg) & $2.900-3.100$ & $3.000-3.200$ & $3.801,9$ \\
\hline
\end{tabular}

Keterangan: * Pakan komersial BR1 dan BR2 ${ }^{* *}$ Jagung lokal Tunu'ana di NTT (Bora et al, 2019)

Tabel 2. Komposisi dan kandungan nutrisi pakan perlakuan penelitian

\begin{tabular}{lcc}
\hline \multirow{2}{*}{ Komposisi } & \multicolumn{2}{c}{ Perlakuan Pakan } \\
\cline { 2 - 3 } & $\mathrm{P}_{1}^{*}$ & $\mathrm{P}_{2}{ }^{* *}$ \\
\hline Protein kasar (\%) & 20 & 17,53 \\
Lemak kasar (\%) & 5 & 8,32 \\
Serat kasar (\%) & 5 & 7,60 \\
Kalsisum (\%) & 0,7 & 0,13 \\
Pospor (\%) & 0,6 & 319,05 \\
Energi metabolis (kkal/kg) & $3.000-3.200$ & $3.240,57-3.380,57$ \\
\hline
\end{tabular}

Keterangan: ${ }^{*}$ Pakan komersial BR2 100\% $\left(\mathrm{P}_{1}\right)$

${ }^{* *}$ Pakan BR2 70\% + jagung lokal 30\% $\left(\mathrm{P}_{2}\right)$ berdasarkan hasil perhitungan. 


\section{Rancangan Perlakuan Penelitian}

Penelitian ini adalah penelitian ekperimen dengan desain eksperimen yang digunakan adalah Rancangan Acak Lengkap (RAL) pola faktorial yang terdiri dari 2 faktor, yaitu faktor pertama adalah strain pejantan (pejantan Sabu $><$ Isa Brown $=$ Saras, Bangkok $><$ Isa Brown = Bakoras dan Legund $><I s a$ Brown = Leguras) dan faktor kedua adalah perlakuan pakan $\left(\mathrm{P}_{1}\right.$ dan $\left.\mathrm{P}_{2}\right)$. Dengan demikian diperoleh pola faktorial $3 \times 2$ yang menghasilkan 6 kombinasi perlakuan, yakni: ayam Saras diberi pakan $\mathrm{P}_{1}\left(\mathrm{SP}_{1}\right)$, Saras diberi pakan $\mathrm{P}_{2}\left(\mathrm{SP}_{2}\right)$, Bakoras diberi pakan $\mathrm{P}_{1}\left(\mathrm{BP}_{1}\right)$, Bakoras diberi pakan $\mathrm{P}_{2}\left(\mathrm{BP}_{2}\right)$, Leguras diberi pakan $\mathrm{P}_{1}\left(\mathrm{LP}_{1}\right)$ dan Leguras diberi pakan $\mathrm{P}_{2}\left(\mathrm{LP}_{2}\right)$. Setiap kombinasi perlakuan diulangi 3 kali sehingga menghasilkan 18 unit percobaan dengan jumlah ayam setiap ulangan adalah 4 ekor.

\section{Variabel Penelitian}

Variabel yang diamati dalam penelitian ini adalah nilai Indeks Performans (IP) dan Income Over Feed and Chick Cost (IOFCC).

Nilai IP dihitung dengan rumus berikut:

$I P=\frac{(100-\% \text { ayam mati) } \times B B \text { akhir }(\mathrm{kg})}{F C R \times \text { umur panen (hari) }} \times 100$

IOFCC merupakan pendapatan kotor yang dihitung dengan rumus berikut:

IOFCC $=$ Total pendapatan $(\mathrm{Rp})-$ Total biaya pakan (Rp)-Harga DOC (Rp)

\section{Analisis Data}

Data yang diperoleh dianalisis dengan menggunakan analysis of variance (ANOVA). Jika hasil analisis ragam berpengaruh nyata dilakukan uji Beda Nyata Terkecil (BNT) untuk mengetahui perbedaan antara kombinasi perlakuan. Proses analisis menggunakan software SPSS versi 21 dan Microsoft Excel.

\section{Prosedur Penelitian}

Ayam pejantan lokal (3 ekor jantan Sabu, 3 ekor Bangkok dan 3 ekor Legund) dilakukan persilangan dengan 27 betina ras petelur Isa Brown dengan inseminasi buatan menggunakan spuite $1 \mathrm{ml}$. Masing-masing pejantan melayani 3 ekor betina dengan dosis semen $0,2 \mathrm{ml} / \mathrm{ekor}$. Telur hasil persilangan ditampung selama seminggu sebanyak 189 butir dilakukan penetasan menggunakan mesin tetas semi otomatis dengan jumlah telur masing-masing strain 63 butir. Tingkat fertilitas dan daya tetas masing-masing strain hasil silangan bervariasi, dimana: telur ayam Saras tingkat fertilitas 69\% dengan daya tetas $57 \%$, ayam Bakoras tingkat fertilitas $75 \%$ dengan daya tetas $56 \%$ dan Leguras tingkat fertilitas $67 \%$ dengan daya tetas $58 \%$. Ayam DOC hasil silangan ini langsung ditimbang bobot tetasnya sebelum 24 jam setelah tetas, kemudian diberikan larutan air gula dan ditempatkan pada indukan buatan. Pakan yang digunakan pada fase starter adalah pakan komersial BR1 sedangkan pada fase grower diberikan pakan $\mathrm{P}_{1}$ dan $\mathrm{P}_{2}$ dengan ferkuensi pemberian pakan $2 \mathrm{x}$ sehari. Proses penimbangan bobot badan ayam dilakukan setiap minggu hingga pada umur 60 hari. Bobot badan hari ke60 merupakan bobot jual yang diestimasi berdasarkan harga ayam lokal di pasar tradisional Kota Kupang.

\section{Konsep Operasional}

1. Pendapatan adalah hasil penjualan yang diestimasi dengan cara berat badan akhir ayam penelitian $\mathrm{X}$ harga ayam lokal per $\mathrm{kg}$ sesuai strain di pasar tradisional Kota Kupang (rupiah/ekor) tahun 2018 yakni ayam Saras Rp92.206,15/kg, ayam Bakoras Rp11.7464,97/kg dan ayam Leguras Rp99.034,41/kg (hasil survei).

2. Ayam F1 hasil silangan (Saras, Bakoras dan Leguras) diberi estimasi harga Rp12.000/ekor sesuai harga ayam Super yang beredar di Kota Kupang tahun 2018.

3. Harga pakan komersial ayam ras pedaging baik BR1 maupun BR2 yang digunakan dalam penelitian adalah Rp365.000/50kg pada tahun 2018.

4. Harga jagung giling lokal yang beredar di pasar tradisional Kota Kupang adalah Rp5.000/kg pada tahun 2018.

\section{HASIL DAN PEMBAHASAN}

\section{Indeks Performans}

Salah satu kriteria yang digunakan untuk mengetahui keberhasilan pemeliharaan ayam adalah Indeks Performa (IP). Nilai IP dihitung berdasarkan bobot badan siap potong, konversi pakan, umur panen dan jumlah persentase ayam yang hidup selama pemeliharaan (Kamara, 2009 
Tabel 3. Rataan nilai indeks performa per ekor

\begin{tabular}{lllllc}
\hline \multirow{2}{*}{ Perlakuan } & & \multicolumn{5}{c}{ Komponen IP } \\
& BBA $(\mathrm{kg} / \mathrm{e})$ & \% ayam mati & Umur panen(hari) & Konversi pakan & IP \\
\hline $\mathrm{SP}_{1}$ & $1,01 \pm 63,52$ & 0 & 60 & $2,19 \pm 0,15$ & $77,53 \pm 9,62^{\mathrm{a}}$ \\
$\mathrm{SP}_{2}$ & $0,81 \pm 1,39$ & 0 & 60 & $2,71 \pm 0,01$ & $50,04 \pm 0,29^{\mathrm{b}}$ \\
$\mathrm{BP}_{1}$ & $1,04 \pm 13,51$ & 0 & 60 & $2,18 \pm 0,03$ & $79,07 \pm 1,98^{\mathrm{a}}$ \\
$\mathrm{BP}_{2}$ & $0,91 \pm 26,46$ & 0 & 60 & $2,48 \pm 0,08$ & $61,32 \pm 3,78^{\mathrm{c}}$ \\
$\mathrm{LP}_{1}$ & $0.84 \pm 33,94$ & 0 & 60 & $2,64 \pm 0,11$ & $53,35 \pm 4,40^{\mathrm{bc}}$ \\
$\mathrm{LP}_{2}$ & $0,79 \pm 18,53$ & 0 & 60 & $2,77 \pm 0,07$ & $47,77 \pm 2,24^{\mathrm{c}}$ \\
$\mathrm{SE}$ & & & & & 2,740 \\
Sig & & & & & 0,006 \\
\hline
\end{tabular}

Keterangan: Superskrip yang berbeda pada kolom yang sama menunjukkan perbedaan yang nyata $(\mathrm{P}<0,05)$

dalam Nurhayati, 2019). Rataan nilai IP ayam Saras, Bakoras dan Leguras yang diberi pakan komersial $100 \%\left(\mathrm{P}_{1}\right)$ dan pakan komersial $70 \%+$ jagung lokal $30 \%\left(\mathrm{P}_{2}\right)$ dapat dilihat pada Tabel 3 . Hasil analisis ragam menunjukkan interaksi antara faktor pakan dan strain pejantan lokal yang berbeda berpengaruh sangat nyata $(\mathrm{P}<0,01)$ terhadap nilai IP. Uji lanjut BNT juga menunjukkan perbedaan nilai IP yang nyata antara kombinasi perlakuan. Rataan nilai IP tertinggi diperoleh pada kombinasi perlakuan $\mathrm{BP}_{1}$ $(79,07 \pm 1,98)$ dan $\mathrm{SP}_{1}(77,53 \pm 9,62)$, kemudian diikuti perlakuan $\mathrm{BP}_{2} \quad(61,32 \pm 3,78), \quad \mathrm{LP}_{1}$ $(53,35 \pm 4,40), \quad \mathrm{SP}_{2} \quad(50,04 \pm 0,29) \quad$ dan $\quad \mathrm{LP}_{2}$ $(47,77 \pm 2,24)$.

Mengacu pada hasil statistik Tabel 3, ayam Bakoras dan Saras pakan $\mathrm{P}_{1}$ memberi nilai IP tertinggi, yang kemudian diikuti ayam Bakoras pakan $\mathrm{P}_{2}$ dan Leguras pakan $\mathrm{P}_{1}$. Namun, ayam Leguras pakan $P_{1}$ memberi nilai IP yang sama secara statistik dengan ayam Saras dan Leguras pakan $\mathrm{P}_{2}$. Rataan nilai IP pada semua kombinasi perlakuan menunjukkan ayam Saras, Bakoras dan Leguras yang diberi pakan $\mathrm{P}_{1}$ nyata lebih tinggi dibandingkan ayam yang diberi pakan $\mathrm{P}_{2}$.

Semakin besar nilai IP, semakin baik prestasi ayam dan semakin efisiensi penggunaan pakan (Fadilah et al, 2007). Rataan nilai IP tertinggi semua kombinasi perlakuan dalam penelitian ini diperoleh perlakuan $\mathrm{BP}_{1}$ dan $\mathrm{SP}_{1}$

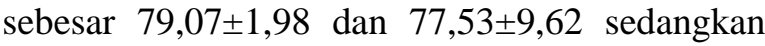
standar nilai IP yang baik dalam usaha peternakan ayam adalah >300 (Santoso dan Sudaryani, 2009). Selanjutnya, Nurhayati (2019) melaporkan bahwa analisis performans ayam broiler pada kandang tertutup dan kandang terbuka menunjukkan IP yang rendah dengan nilai $<300$.

Nilai IP yang diperoleh dalam penelitian ini belum dikategorikan baik meskipun semua kombinasi perlakuan memberikan profit yang positif. Rendahnya nilai IP semua kombinasi perlakuan dalam peneltian ini dikarenakan tingginya nilai konversi pakan. Nilai konversi pakan yang tinggi menunjukkan efisiensi pakan yang kurang baik, sebaliknya nilai konversi pakan yang rendah menunjukkan semakin efisien pakan yang dimanfaatkan oleh ternak (Aryanti et al, 2013).

\section{Income Over Feed and Chick Cost}

Income over feed and chick cost (IOFCC) merupakan indikator nilai ekonomis dari pakan dan DOC yang diberikan pada ternak ayam. IOFCC adalah besarnya keuntungan kotor yang diperoleh dari hasil penjualan bobot hidup seekor ayam dikurangi biaya pakan yang dikonsumsi dan biaya pembelian DOC (Nurhayati et al, 2015). Rataan IOFCC pada ayam Saras, Bakoras dan Leguras yang diberi perlakuan pakan $\mathrm{P}_{1}$ dan pakan $\mathrm{P}_{2}$ dapat dilihat pada Tabel 4.

Hasil analisis ragam menunjukkan interaksi faktor pakan dan faktor strain pejantan lokal beda strain berpengaruh sangat nyata terhadap nilai IOFCC. Uji lanjut BNT juga menunjukkan perbedaan nilai IOFCC yang nyata antara kombinasi perlakuan. Rataan IOFCC tertinggi diperoleh pada kombinasi perlakuan $\mathrm{BP}_{1}$ (Rp93,955.15 $\pm 1.550,69)$ diikuti perlakuan $\mathrm{BP}_{2}$ (Rp80,567.32 $\pm 3.150,40)$ dan perlakuan $\mathrm{SP}_{1}$ (Rp66,071.23 $\pm 5.818,03)$. Selanjutnya rataan IOFCC menurun dan berbeda tidak nyata pada perlakuan $\mathrm{LP}_{1} \quad(\mathrm{Rp} 56,091.82 \pm 3.305,32), \quad \mathrm{LP}_{2}$ $(\mathrm{Rp} 52,543.05 \quad \pm \quad 1.836)$ dan $\mathrm{SP}_{2}$ (Rp48,895.47 $\pm 153,61)$. Tabel 4 menunjukkan rataan nilai IOFCC tertinggi adalah ayam Bakoras pakan $\mathrm{P}_{1}$ diikuti ayam Bakoras pakan $\mathrm{P}_{2}$ dan ayam Saras pakan $\mathrm{P}_{1}$. Selanjutnya, rataan nilai IOFCC menurun dan sama secara statistik pada perlakuan ayam Leguras pakan $\mathrm{P}_{1}$ serta ayam Leguras dan Saras yang diberi pakan $\mathrm{P}_{2}$. 
Tabel 4. Rataan IOFCC (Rp/ekor)

\begin{tabular}{lllll}
\hline \multirow{2}{*}{ Perlakuan } & \multicolumn{4}{c}{ Komponen IOFC } \\
\cline { 2 - 5 } & Biaya pakan (Rp/e) & Harga DOC $($ Rp/e) & Pendapatan (Rp/e) & \multicolumn{1}{c}{ IOFCC (Rp/e) } \\
\hline $\mathrm{SP}_{1}$ & $15.502,65 \pm 52,25$ & 12.000 & $93.573,88 \pm 5.856,92$ & $66.071,23 \pm 5.818,03^{\mathrm{a}}$ \\
$\mathrm{SP}_{2}$ & $14.137 .28 \pm 64,63$ & 12.000 & $75.032,76 \pm 128,35$ & $48.895,47 \pm 153,61^{\mathrm{b}}$ \\
$\mathrm{BP}_{1}$ & $15.748,35 \pm 47,12$ & 12.000 & $121.703,50 \pm 1.587,23$ & $93.955,15 \pm 1.550,69^{\mathrm{c}}$ \\
$\mathrm{BP}_{2}$ & $14.521,58 \pm 45,58$ & 12.000 & $107.088,90 \pm 3.108,15$ & $80.567,32 \pm 3.150,40^{\mathrm{d}}$ \\
$\mathrm{LP}_{1}$ & $15.427,21 \pm 62,62$ & 12.000 & $83.519,02 \pm 3.361,46$ & $56.091,82 \pm 3.305,32^{\mathrm{b}}$ \\
$\mathrm{LP}_{2}$ & $14.115,03 \pm 21,89$ & 12.000 & $78.658,08 \pm 1.834,98$ & $52.543,05 \pm 1.836^{\mathrm{b}}$ \\
$S E$ & & & & $1.833,32$ \\
Sig & & & & 0,008 \\
\hline
\end{tabular}

Keterangan: Superskrip yang berbeda pada kolom yang sama menunjukkan perbedaan yang nyata $(\mathrm{P}<0,05)$

Seluruh kombinasi perlakuan menunjukkan ayam Bakoras, Leguras dan Saras yang diberi pakan $\mathrm{P}_{1}$ memberikan nilai IOFCC yang lebih tinggi dibandingkan pakan $\mathrm{P}_{2}$, namun perlakuan ayam Bakoras Pakan $\mathrm{P}_{2}$ memperoleh nilai IOFCC yang lebih tinggi dibandingkan ayam Saras dan Bakoras pakan $\mathrm{P}_{1}$.

Perbedaan nilai IOFCC pada semua perlakuan dalam penelitian ini dikarenakan perbedaan tingkat konsumsi pakan, kandungan nutrisi pakan, harga pakan dan genetik ayam Saras, Bakoras dan Leguras. Hal ini sejalan dengan pendapat Sihombing (2006) dalam Sobang et al (2018) yang menyatakan bahwa untuk menilai perhitungan ekonomis dalam pemberian pakan ayam perlu memperhatikan berapa besar biaya pakan sebagai input dan seberapa besar pertambahan bobot badan sebagi output. Selanjutnya, Rasyaf (2004) menyatakan besarnya nilai IOFCC dipengaruhi oleh konsumsi ransum, pertambahan berat badan, biaya pakan dan harga jual per ekor.

\section{KESIMPULAN}

Berdasarkan hasil analisis dan pembahasan dapat disimpulkan bahwa: interaksi antar faktor pakan dan faktor strain pejantan lokal berpengaruh sangat nyata $(\mathrm{P}<0,01)$ terhadap indeks performans dan income over feed and chick cost. Kombinasi kedua faktor yang terbaik diperoleh pada perlakuan ayam Bakoras menggunakan pakan komersial $100 \%$, dimana nilai indeks performans $(79,07 \pm 1,98)$ dan income over feed and chick cost (Rp. 93.955,15 $\pm 1.550,69 /$ ekor). Dapat disarankan bahwa: 1) untuk mencapai performans dan efisiensi ekonomi yang baik dalam pengembangan usaha ternak ayam maka disarankan penggunaan ayam Bakoras dengan menggunakan ransum komersial 100\%; dan 2) perlu adanya kajian lanjutan mengenai kualitas nutrisi dan organoleptik daging ayam F1 hasil persilangan (ayam Saras, Bakoras dan Leguras).

\section{DAFTAR PUSTAKA}

Aryanti, F., M. B. Aji dan N. Budiono. 2013. Pengaruh pemberian gula merah terhadap performa ayam kampung pedaging. Jurnal Veteriner 31(2): 156-164.

Bora, C. Y., T. Murningsih, K. S. Yulita dan I. G. B. A. Arsa. 2019. Kandungan proksimat dan mineral jagung varietas lokal (Tunu'ana') dari Nusa Tenggara Timur. Pros. Sem. Nas. Masy. Biodiv. Indon. 5(1):107-111.

Bandu, I. S., H. Sutedjo dan I. G. N. Jelantik. 2015. Pengaruh strain pejantan terhadap daya tetas dan berat DOC dari induk ayam petelur strain CP 909. Jurnal Nukleus Peternakan 2 (2): 179-185.

Beramang, E. S. 2012. Studi komparatif kandungan nutrisi jagung lokal dan jagung hibrida di Kabupaten Flores Timur, Nusa Tenggara Timur. Thesis. Program Pascasarjana. Universitas Kristen Satya Wacana, Salatiga.

Djegho, Y. dan J. N. Kihe. 2019. Efek komposisi genotip dari ayam ras petelur, kate dan lokal sabu terhadap sifat-sifat pada bobot badan dan ukuran tubuh. Jurnal Nukleus Peternakan 6 (1): 20-25.

Fadillah, R., A. Polana, S. Alam dan E. Parwanto. 2007. Sukses Beternak Ayam Broiler. Agromedia Pustaka, Jakarta. 
Gaspersz, V. 2006. Teknik Analisis dalam Penelitian Percobaan. Cetakan Ketiga. Tarsito. Bandung.

Kaleka, N. 2015. Beternak Ayam Kampung Super Tanpa Bau. Cetakan: I, Arcitra. Yogyakarta.

Lapihu, Y. L., F. M. S. Telupere dan H. Sutedjo. 2019. Kajian fenotip dan genetik performa pertumbuhan dari persilangan ayam lokal dengan ayam ras petelur Isa Brown. Jurnal Sains Peternakan Indonesia 14(3): 298-305.

Nawawi, N. T. dan Nurrohmah. 2011. Pakan Ayam Kampung. Penebar Swadaya, Jakarta.

Nurhayati, C. U., Wirawati dan D. D. Putri. 2015. Penggunaan produk terfermentasi dan kunyit dalam pakan terhadap performa ayam pedaging dan income over feed and chick cost. Jurnal Zootek 35(2): 379-389.

Nurhayati, T. 2019. Analisis performans ayam broiler pada kandang tertutup dan kandang terbuka. Jurnal Peternakan Nusantara 5 (2): 77-86.
Rasyaf, M. 1992. Seputar Makanan Ayam Kampung. Penerbit Kanisius, Yogyakarta.

Santoso, H. dan T. Sudaryani. 2009. Pembesaran Ayam Pedaging di Kandang Panggung Terbuka. Penebar Sawadaya, Jakarta.

Shidiq dan M. Amarullah. 2016. Penampilan Produksi Strain Ayam Petelur (Lohman Brown vs Isa Brown). Thesis. Universitas Brawijaya.

Suprijatna, E. 2005. Ayam Buras Krosing Petelur. Penebar Swadaya, Jakarta.

Sobang, R. L., N. P. F. Suryatni dan S. M. Makandolu. 2018. Nilai ekonomis larva dari feses sapi pada ayam buras. Jurnal Nukleus Peternakan 5 (1): 56-63.

Telupere, F. M. S. dan H. Sutedjo. 2016. Kajian Fenotip Hasil Persilangan antara Ayam Buras dengan Ayam Ras Petelur Jenis CP 909. Proposal Hibah Penelitian Pascasarjana. Program Studi Ilmu Peternakan. Undana. Kupang. 